\title{
Correction to: Feasibility, Safety, and Efficacy of an Alternative Schedule of Sunitinib for the Treatment of Patients with Metastatic Renal Cell Carcinoma: A Retrospective Study
}

\author{
Sebastiano Buti ${ }^{1} \cdot$ Maddalena Donini $^{2} \cdot$ Melissa Bersanelli $^{1} \cdot$ Alessia Gattara $^{1}$ • \\ Francesco Leonardi ${ }^{1} \cdot$ Rodolfo Passalacqua $^{2}$
}

Published online: 28 May 2018

(C) The Author(s) 2018

\section{Correction to:}

Drugs R D https://doi.org/10.1007/s40268-017-0209-5

In the Original Publication of the article, In Introduction part, 7th line, the value " $5-100 \mathrm{nM}$ " has been published incorrectly. The correct value should read as "Plasma concentration of $50-100 \mathrm{ng} / \mathrm{ml}$ ". In the Original Publication of the article, page 591, Table 2 has been published incorrectly. The corrected table is shown below:
Open Access This article is distributed under the terms of the Creative Commons Attribution-NonCommercial 4.0 International License (http://creativecommons.org/licenses/by-nc/4.0/), which permits any noncommercial use, distribution, and reproduction in any medium, provided you give appropriate credit to the original author(s) and the source, provide a link to the Creative Commons license, and indicate if changes were made.

Table 2 Delivered treatment, dose reductions and interruptions

\begin{tabular}{lll}
\hline & Sunitinib 4/2 schedule & Sunitinib modified schedule \\
\hline Median time from start to switch, months (range) & $2.9(1.4-16.5)$ & - \\
Median duration of treatment after switch, months (range) & - & $9.2(0.5-32.4)$ \\
Mean actual daily dose intensity, mg (range) & $46.1(20.8-50.0)$ & $44.3(17.9-71.8)$ \\
Mean relative dose intensity, \% (range) & $92.3(42-100)$ & $88.7(36-144)$ \\
Total cycles, number & 88 & 164 \\
Median cycles, number (range) & $2(1-11)$ & $5(1-20)$ \\
Patients with a dose reduction, number $(\%)$ & $3(12)$ & $3(12)$ \\
Patients with a dose interruption, number $(\%)$ & $7(28)$ & $12(48)$ \\
Number of dose interruptions corrected for number of cycles $(\%)$ & $0.10(10)$ & $0.11(11)$ \\
Patients still on treatment, number $(\%)$ & - & $2(16)$ \\
\hline
\end{tabular}

The original article can be found online at https://doi.org/10.1007/ s40268-017-0209-5.

\footnotetext{
Melissa Bersanelli bersamel@libero.it

1 Medical Oncology Unit, University Hospital of Parma, Via Gramsci 14, 43126 Parma, Italy

2 Oncology Unit, Oncology Department, ASST Ospedale di Cremona, Cremona, Italy
} 